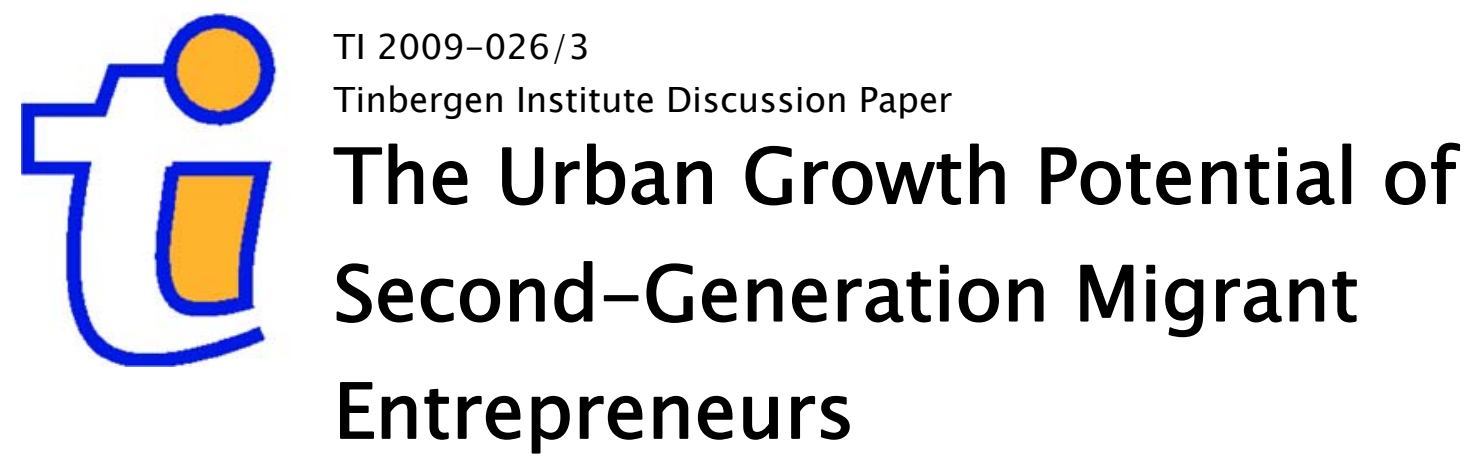

Tüzin Baycan-Levent ${ }^{1}$

Peter Nijkamp ${ }^{2,3}$

Mediha Sahin²

' Istanbul Technical University;

2 VU University Amsterdam;

3 Tinbergen Institute. 


\section{Tinbergen Institute}

The Tinbergen Institute is the institute for economic research of the Erasmus Universiteit Rotterdam, Universiteit van Amsterdam, and Vrije Universiteit Amsterdam.

Tinbergen Institute Amsterdam

Roetersstraat 31

1018 WB Amsterdam

The Netherlands

Tel.: +31(0)205513500

Fax: $+31(0) 205513555$

Tinbergen Institute Rotterdam

Burg. Oudlaan 50

3062 PA Rotterdam

The Netherlands

Tel.: + $31(0) 104088900$

Fax: $+31(0) 104089031$

Most TI discussion papers can be downloaded at http://www.tinbergen.nl. 


\title{
The Urban Growth Potential of Second-Generation Migrant Entrepreneurs \\ A Sectoral Study on Amsterdam
}

Tüzin Baycan-Levent Dept. of Urban and Regional Planning Istanbul Technical University Istanbul Turkey tuzin.baycanlevent@itu.edu.tr

\author{
Peter Nijkamp \\ Dept. of Spatial Economics \\ Free University \\ Amsterdam \\ The Netherlands \\ pnijkamp@feweb.vu.nl
}

\author{
Mediha Sahin \\ Dept. of Spatial Economics \\ Free University \\ Amsterdam \\ The Netherlands \\ msahin@feweb.vu.nl
}

Pn319tblms

\begin{abstract}
This study focuses on the external orientations of the second-generation migrant entrepreneurs by addressing in particular the way - and the extent to which - the choice for entrepreneurship is made by higher-educated young ethnic generations. The empirical data of our study is based on in-depth personal interviews. We employed a recently developed multivariate qualitative classification method, called rough set analysis, in order to investigate the motivation, goals, and strategies of second-generation Turkish entrepreneurs in the ICT and the FIRE (i.e. Finance, Insurance and Real Estate) sectors in the Netherlands. The results of our study show that the second generation Turkish entrepreneurs in the Netherlands have started to be involved in new and non-traditional sectors like the ICT and FIRE sectors. The motivation and driving forces of the second-generation Turkish entrepreneurs stem from both their personal characteristics, shaped by their higher educational level, and their previous working experience as employees or entrepreneurs in the same sector.
\end{abstract}

Keywords: second-generation migrant entrepreneurs, sectoral change in migrant entrepreneurship, Turkish migrant entrepreneurs, ICT and FIRE sectors, Amsterdam

1. The New Demography as an Entrepreneurial Driver 
Innovation - a significant improvement (and market acceptance) of (part of) our production or governance systems - has been a central instrument of any market-driven economy since the early history of mankind. It has been a focal point of economic theory and applied economic research since the postwar period, with different cycles of interest in the past 60 years. A first wave of economic interest can be found in Schumpeterian theory on innovation and entrepreneurship (see Schumpeter, 1957). Later, the recession at the beginning of the 1980s prompted a new phase of interest instigated by a revival of long wave (Kondratieff) theory (see Kleinknecht 1982). And, finally, in recent years we have witnessed another wave of interest in innovation and entrepreneurship, mainly as a result of global competition, on the one hand, and reinforcement of local growth potential, on the other (see de Groot et al. 2004).

The competition dynamics in different parts of the world and with multiple stakeholders has shifted the attention from conventional market pull versus technology-push dilemmas towards the acceptance of a Triple Helix paradigm, in which the interface between industry, knowledge institutions and governance agencies has become a central field of attention (see Leydesdorff and Etzkowitz, 1998). In this context, new economic analysis frameworks - in particular, endogenous growth (see Aghion, 2002; Lucas, 1988; Nijkamp and Poot, 1998; Romer, 1990), the new economic geography (Fujita and Krugman, 2004), and evolutionary economics (see, e.g., Boschma and Lambooy, 2001; Nelson and Winter, 1982; and van den Bergh et al., 2007) have highlighted the importance of strategic behaviour of economic actors and entrepreneurs at a micro-scale on a local or regional level.

Economic analysis of spatial-economic dynamics and innovation has mainly centered around new technological regimes, market regimes and institutional regimes. Far less attention has been given to demographic regimes (for an interesting exception see Poot, 2007). But it ought to be recognized that demographic forces - mainly as a result of international migration - exert a significant impact on the economic development and innovative potential of countries and regions. For example, a large share of the innovation success of the USA can be ascribed to the influx of foreigners who created an innovative spirit in an uncertain economic climate.

In an open and globalizing world it seems plausible that international mobility will be on a rising curve, starting from the business, R\&D and knowledge sector, but increasingly spreading out to other sectors of the economy (e.g. medical care, consultancy, etc.). The entry into the labour market of host countries by foreign workers is often fraught with many problems (due to the existence of language, institutional, and cultural barriers), and hence many migrants are stimulated to become self-employed. Self-employed migrants are increasingly resorting to what is called ethnic (or migrant) entrepreneurship (see Baycan-Levent et al., 2003, 2006; Jones and Ram, 2007; Rath, 2000; Stiles and Galbraith, 2004; Waldinger et al., 1990; Ward and Jenkins, 1984). A wealth of scientific contributions and reviews on ethnic entrepreneurship can be found in Dana (2007). Migrant entrepreneurs are typically found in traditional sectors of the urban economy: for instance, in the retail, hospitality, and repair sector. But, in recent years, we have observed a gradual upgrading of these entrepreneurs towards higher levels, e.g.,consultancy, ICT services, legal services, and so forth, in particular by second-generation migrant entrepreneurs. The latter category will be the focus of the present study. 
The present paper aims to study the shift in migrant entrepreneurship towards promising and modern urban economic sectors. As an example, we will take the involvement of migrant entrepreneurs in the ICT and the FIRE sectors in the city of Amsterdam. We will offer an analysis of critical success conditions and barriers for these businesses, based on extensive structured interviews with these entrepreneurs. The - mainly qualitative - information from these interviews will be systematically integrated in a coded nominal (alpha-numerical) survey table, which will be further analysed by means of rather novel technique from the artificial intelligence literature, viz. rough set analysis. The paper will conclude with some retrospective and prospective remarks.

\section{The Second Cycle in Migrant Entrepreneurship}

Europe has become an 'epicentre' of immigration (van de Kaa, 1996). European cities have demonstrated a remarkable demographic change, with a large influence of foreign migrants in recent decades. Between 1975 and 2000, the population of Europe grew from 349 to 375 million (Brücker et al., 2002). Nowadays, several districts in European cities have a majority of foreigners, and within the next two decades several European cities will have a majority of first- and second-generation migrants. European cities are becoming cultural melting pots (see Jacobs, 1961).

The influx of many migrants into the urban economies of many European countries has led to a socio-economic differentiation accompanied by persistent disparities on urban labor markets that is reflected in (i) relatively high unemployment rates of migrants; and (ii) a concentration of migrant workers in lower segments of the labour market leading to a dual labour market (see Piore and Sabel, 1984). Many migrants do not appear to meet the requirements for professional human capital in a modern economy, and hence are condemned to resort to the types of jobs which require lower qualifications. However, as well as professional human capital, any developed economy also needs entrepreneurial human capital (see lyigun and Owen, 1998). However, entrepreneurial spirit is a scarce good that can be acquired by training, education or learning mechanisms through the pressure of economic circumstances (as is also witnessed in resource dependence theory). There is an abundance of literature on entrepreneurship (see for surveys Audretsch and Thurik, 2001; Hébert and Link, 1989; Lumpkin and Dess, 1996; Wennekers and Thurik, 1999). In general, creativeness, risk-taking behavior, courage, technological and market knowledge, as well as human and social skills, are usually regarded as necessary background factors for successful entrepreneurship.

In the modern literature on entrepreneurship, we sometimes come across the term 'entrepreneurial hero', suggesting that successful entrepreneurial behaviour presupposes a series of jumps leading to high performance. However, some realism is needed here, as most business innovations are incremental in nature (see Kassichieh et al., 2002). In many cases, successful business-making is only based on variational imitation, where certain products or services in a new domain are offered as a variant of a new or existing product or service (see lyigun and Owen, 1998). Thus, one may assume that incremental innovations are mainly taking place under conditions of monopolistic competition. It is obvious 
that risk attitudes and avoidance are key ingredients of an entrepreneurship culture present in a monopolistic competition market (Hofstede, 1991).

Many migrant entrepreneurs have their roots in a local, small-scale and network-based culture and are thus dependent on the socio-cultural urban incubation climate - and will often be inclined to start up a new business from a risk-avoiding attitude (see, e.g., the mixed embeddedness perspective, advocated by Kloosterman and Rath, 2001). This explains their presence in traditional markets where there is still a sufficient critical mass of demand for indigenous ethnic products or services, without a requirement for knowledge-intensive products or services (the 'pizza' phenomenon). But with mass competition and the introduction of new products - and thus more market opportunities - there will be a trend towards developing new and more promising SME market niches, especially by second-generation migrants (see also Cooper, 2003; Malecki, 1997).

Consequently, we observe the emergence of a second cycle where migrant entrepreneurs increasingly penetrate a new knowledge-intensive product or service market. This requires an upscaling of human capital, with more competition outside the traditional ethnic domain. This prompts diversity in the supply of products and services and leads to more competitive marketing actions. This transition will also challenge the traditional network cooperation model of migrant entrepreneurs in their own ethnic or sociocultural niche. Simultaneous competition and cooperation will become the new features of the markets for migrant entrepreneurs, where local embeddedness and sector-specific innovative cultures are key ingredients (see Markusen, 1996). This emerging case of monopolistic competition is already visible in new knowledge-intensive fields like ICT, consultancy, export services, marketing, etc. It may seem realistic that this second phase of knowledge-intensive entrepreneurship may pave the way towards the final stage of mature entrepreneurship, viz. a break-out towards entirely new and modern markets.

Later in this paper (in Section 4), we will investigate the second cycle of migrant entrepreneurship in the ICT and the FIRE sector in Amsterdam. The next section will be devoted to an overview of migrants and entrepreneurship in the Netherlands.

\section{Migrants and Entrepreneurship in the Netherlands}

\subsection{Migration and immigrants: the case of the Netherlands}

The Netherlands has a long international and national migration history (for a discussion of immigration flows in different periods, see Kraal and Zorlu, 1998; Lucassen and Penninx, 1997; Zorlu and Hartog, 2001). In the postwar period, political processes and economic developments determined migration to the Netherlands and the country switched from an emigration into an immigration country. By the mid-1950s, the Dutch economy began to grow, and this led to a labour shortage of unskilled workers in certain sectors, such as industry and mining. The demand for workers for unskilled jobs was increasing, while the supply of unskilled Dutch workers was decreasing. The shortage of unskilled workers was compensated by an inflow of Mediterranean workers (Hartog and Vriend, 1990). Guest workers were actively recruited from Mediterranean countries; Italy, Spain, Portugal, Turkey, Greece, Morocco, 
Yugoslavia, and Tunisia. The recruitment policy stopped during the first oil crisis, but the immigration from the recruitment countries continued as chain-migration in the form of family reunification (1970s) and family formation (1980s and 1990s). In addition, the flow of political refugees and asylum seekers from politically unstable areas in the world also increased in this period. Therefore, in only three decades, the non-Western population grew from 160,000 in 1972, to 1.7 million in 2004 (Tillie and Slijper, 2006). Ultimately, Surinamese, Antilleans, Turks, and Moroccans became the largest migrant minority groups, and this group is gradually growing as a result of a combination of continuous immigration and a relatively high birth rate. Nevertheless, immigration streams are now increasingly dominated by political refugees and asylum seekers.

\section{Figure 1 about here}

In the past three decades, non-Western immigrants were responsible for half of the population growth in the Netherlands (Garssen and Zorlu, 2005), and the increase of non-Western immigrants has been partially caused by the growing share of second-generation immigrants. According to the latest data of CBS (2007), in the last ten years, since 1996, the sharpest rise in the absolute numbers of secondgeneration immigrants was amongst Moroccans with 70,219, followed by Turks with 64,356 (see Figure 1).

This increase in the number of first- and second-generation non-Western immigrants in the Netherlands meant that more attention was given to socio-cultural position and structural integration of immigrants (see Bijl et al., 2005; Dagevos et al., 2003). The socio-economic characteristics of migrants living in the Netherlands can be summarized by the following stylized facts: migrants are younger than natives; the proportion of males is higher in the migrant population than in the native population; migrants are concentrated in large cities: Rotterdam, Amsterdam, The Hague and Utrecht; the skill levels of migrants may be below those of the native population; and their occupational status is below that of natives with comparable skill levels. Finally, migrants are more than proportionally affected by unemployment (Brücker et al., 2002). However, a comparative evaluation between the first and the second generation within the different immigrant groups shows that the level of education differs considerably between the first- and the second-generation immigrants. The first-generation immigrants have a lower level of education compared with the Dutch natives, whereas the second-generation immigrants do not differ significantly from the Dutch natives (Zorlu and Traag, 2005). Because of their better educational level, the second-generation immigrants in general have a better position in the labour market than the first generation. However, in 2004, after years of economic recession, the labour market participation of immigrants decreased to 48 per cent, and the unemployment rate was 16 per cent among immigrants, three times higher compared with that of the native Dutch (Zorlu and Traag, 2005). This led to increasing numbers of first- and second-generation immigrants choosing to become self-employed.

After this historical overview of immigration and the current situation of immigrants in the Netherlands, we will now discuss the labour market position of different migrant groups and migrant entrepreneurship in the Netherlands. 


\subsection{Migrant entrepreneurship in the Netherlands}

Since the late 1980s, the number of immigrant entrepreneurs has risen sharply in the Netherlands. While the total number of entrepreneurs increased from 925,800 to 939,799 between 1999 and 2004 (Table 1), the highest increase was among non-Western immigrants, compared with native and Western entrepreneurs. The number of non-Western entrepreneurs increased from 34,100 in 1999 to 46,900 in 2004, an increase of 3.8 per cent. From 1999 to 2004, amongst Western immigrants, the number of entrepreneurs increased from 72,700 to 74,500 (0.2 per cent), and amongst the native Dutch the number of entrepreneurs decreased from 819,000 to 818,300 . A decrease in the number of native Dutch entrepreneurs is especially observed after 2001. On the other hand, a decrease in the number of Western entrepreneurs after 2003 also should be noted. So, it seems that, while there is an increasing trend to become an entrepreneur among non-Western immigrants, there is a decreasing trend to become an entrepreneur amongst Western immigrants and the native Dutch. This fact can be partly explained by the recession in the Dutch economy after 2001.

\section{Table 1 about here}

Amongst non-Western immigrant entrepreneurs, the highest increase in the number of entrepreneurs was amongst the second-generation immigrant entrepreneurs between 1999 and 2004. While the rate of increase for the first generation was 3.3 per cent, it was 7.4 per cent for the second generation. However, amongst both the first- and the second-generation non-Western immigrants, the self-employment rate lags behind both Western immigrants, as well as the native Dutch (Bijl et al., 2005). While amongst the native Dutch 9.2 percent of the labour force chose to become an entrepreneur in this period, amongst the non-Western immigrants this percentage was 4.1 per cent. Nevertheless, between 1999 and 2003 the self-employment rate of non-Western immigrants increased more rapidly than among native Dutch and Western immigrants. In absolute numbers, the largest group of immigrant entrepreneurs in the Netherlands, from both the first and the second generation, originate from Turkey and Surinam (Table 2). However, in the period 1999-2004, the sharpest rise was among Moroccan entrepreneurs: namely, 64 per cent.

\section{Table 2 about here}

There are considerable differences in the self-employment rates among the different ethnic groups. First-generation Chinese immigrants are most active as entrepreneurs compared with the other ethnic groups. Furthermore, Chinese immigrants choose to become an entrepreneur almost twice as often as the native Dutch (Bijl et al., 2005). On the other hand, the relative growth of the self-employment rate is higher for Turkish immigrants than it is for Chinese immigrants. 
With regard to the sectors in which immigrant entrepreneurs set up their businesses, it appears that, in the past decade, immigrants have more often set up businesses in sectors other than the traditional ones (EIM, 2004; CBS, 2007). Although the hotel and catering industry is still most popular with the first generation, the percentage choosing to set up business in this industry has declined considerably. Instead, the first generation prefers more often to become active as entrepreneurs in other sectors like the business or producer services sectors which include finance, insurance, real estate, and business-related professional services, such as accounting, consulting, marketing, engineering, or design, most of which provide a high number of technical, professional and managerial jobs. The second generation is predominantly represented in the producer services sector. In 2002, one-quarter of the second generation started a business in this sector. As a result, the sectoral distribution of the second generation has become more similar to the native Dutch entrepreneurs than the first generation.

According to the study of Dagevos and Gesthuizen (2005), Surinamese and Antillean entrepreneurs are more often active in producer services than other ethnic groups (Table 3). Amongst Turkish entrepreneurs there is also an above-average increase of entrepreneurs in the producer services.

\section{Table 3 about here}

The research study on first- and second-generation immigrant entrepreneurs in Dutch cities conducted by Rusinovic in 2006 also shows some interesting results concerning the differences between the first- and the second-generation immigrant entrepreneurs. According to the results of this research, which consists of 252 immigrant entrepreneurs in the Netherlands, the first generation, the largest group (31 per cent), is active in an ethnic market, whereas for the second generation this percentage has declined to 15 per cent. The first generation of these entrepreneurs is more often embedded in ethnic markets and depends more than the second generation on both informal and transnational networks in running their businesses. Compared with the first generation, the second generation is more often embedded in mainstream markets (38 per cent), and almost three-quarters of the second generation are at least partially embedded in formal networks. However, Rusinovic has mentioned that this does not mean that the importance of embeddedness in informal networks has disappeared with successive generations. For the second generation entrepreneurs, embeddedness in formal and in informal social networks are not mutually exclusive options, but the formal and informal networks overlap or complement each other. The results of Rusinovic's research also show that the embeddedness in transnational networks still remains of importance for the second generation, but the transnational involvement of the second generation has declined compared with that of the first generation. According to Rusinovic, for the second generation, transnational involvement has become more a strategic choice - 'strategic transnationalism' - whereas for the first generation it is more often a necessity.

An overall evaluation of immigrant entrepreneurship in the Netherlands highlights the changing trends in recent years. The new trends have emerged as: i) a new orientation to non-traditional sectors; ii) sectoral change in immigrant entrepreneurship especially towards producer services; and, iii) an 
increasing number of second-generation immigrant entrepreneurs. Later in this paper (Section 5), we investigate the critical success conditions (and failure conditions) that are decisive for the economic performance of migrant entrepreneurs in the ICT and the FIRE sector in Amsterdam (see also van Oort and Atzema 2004). The ICT market is seen here as a new market (second cycle) for innovative migrant entrepreneurs. The next section will be devoted to a brief description of our database.

\section{Turkish Entrepreneurs in the ICT and the FIRE Sector in Amsterdam: Profile and Database}

\subsection{A sketch of Turkish entrepreneurship in the Netherlands}

The first wave of Turkish immigration to the Netherlands took place in the 1960s and 1970s. The shortage of unskilled labourers led the Dutch government to sign a treaty with the Turkish government for the immigration of what are known as 'guest labourers'. According to Dieleman (1993), many immigrants came to the Netherlands in the 1960s and 1970s to work in the old traditional industries. Dutch companies recruited these people for heavy, unskilled work (Houtzager and Rodrigues, 2002). As elsewhere, they filled the demand for workers at the bottom of the job market. The Netherlands went through a long period of economic growth during these years, and the number of Turkish immigrants grew strongly. The first oil crisis was the end of the official recruitment of Turkish guest workers, and the number of entrants decreased. The occurrence of the second oil crisis caused an economic crisis and a decrease in the demand for workers. Long-term unemployment became a serious problem. After this period, migration from Turkey almost solely consisted of family reunification (bringing wife and children to the Netherlands), family formation (bringing in a marriage partner from her country of origin), and asylum migration. At first, both the Turkish guest workers and the Dutch government thought their stay would be temporary. After a brief working period, these migrants planned to return to their home country with savings accumulated in the Netherlands. Nevertheless, most of the Turkish guest workers decided to stay, and then brought their wives and children to the Netherlands. Many people came to the country because of this family reunification and the Turks became permanent habitants of the Netherlands. As the economic crisis hit the Dutch economy in the 1970s, especially affecting the old industries, many immigrants were faced with exclusion from new job opportunities in the restructured urban economy (e.g. in the services sector), and a number of them tried to make a niche as small business entrepreneurs.

Nowadays, the Turks are the major immigrant group in the country. In 2004, about 350,000 firstand second-generation Turks lived in the Netherlands, which is about 2.2 percent of the Dutch population (Euwals et al., 2007). Turkish immigrants in the Netherlands are, on average younger, than the native Dutch population; they often have more children; and usually they have a lower level of education. Their participation in the labour market lags significantly behind that of the native Dutch population in the Netherlands. The employment rate for Turkish men is 23 percentage points lower than it is for native men (Euwals et al., 2007). The relatively low level of education of Turkish immigrants in the Netherlands may explain the less favorable labour market position of Turkish immigrants in the Netherlands. 
Choenni (1997) noted that more than 10 per cent of the Turkish working population in Amsterdam consists of entrepreneurs, and they constitute about 20 per cent of all ethnic entrepreneurs in Amsterdam. The hospitality sector (restaurants, cafés, bars) is an important domain for Turkish entrepreneurs. Recent research indicates that, in relation to the total population, Turkish entrepreneurs account for the highest percentage of start-ups amongst all groups (including the native Dutch) in the Netherlands: 11.5 per cent of the Turkish working population started their own firm in 2000, versus 6.5 per cent of all other groups (kamer van koophandel, 2006). Jansen et al. (2003) mentioned that, despite certain disadvantages compared with the native Dutch population, immigrants from Turkey show the same rate of entrepreneurship. Although the Turkish immigrants show similar characteristics to other immigrants (from Morocco, Suriname, and the Antilles), their rate of entrepreneurship is much higher. According to Masurel and Nijkamp (2004), Turkish entrepreneurs account for the highest percentage of start-ups amongst all groups, in relation to the total population (including the Dutch native population).

Today, Turks are the largest entrepreneurial group in the country. Furthermore, the relative growth of the entrepreneurship rate is higher among Turkish immigrants, in relation to other non-Western groups. Between 1999 and 2004 the total number of Turkish entrepreneurs in the Netherlands increased from 7,900 to 11,700 (see Table 4). Among Turkish immigrant entrepreneurs there is an increasing group of second-generation immigrants. In 1999, out of the 7,900 Turkish entrepreneurs, 800 were secondgeneration immigrant entrepreneurs, whereas in 2004 out of the 11,700 Turkish entrepreneurs, 1,800 were second-generation. While the rate of increase for the first generation was 1.4 per cent, it was 2.3 per cent for the second generation.

\section{Table 4 about here}

Most Turkish entrepreneurs work in the hospitality sector (bars, cafés, restaurants), but, nowadays, we can see a shift to different sectors. According to Dagevos and Gesthuizen (2005), there is an above-average increase of entrepreneurs in the producer services (finance, insurance, real-estate, and business-related professional services). Therefore, the next section will investigate the motivation, driving forces, goals and strategies of Turkish entrepreneurs in these new sectors.

\subsection{Profile of Turkish entrepreneurs in the ICT and the FIRE sectors}

In our study we aim to explain the qualitative performance or output indicators of Turkish entrepreneurs in the ICT and the FIRE sectors in the city of Amsterdam. The sample of our study consists of a total of 23 Turkish entrepreneurs of whom 16 are active in the ICT sector and 7 are active in the FIRE sector. Our sample considers three groups of companies/entrepreneurs in the ICT sector: automation, software computer programming, and Internet service provider companies; and in the FIRE sector: finance, insurance, real estate, consulting, and accountancy companies that require a higher educational level and skills and, that are very far from any ethnic niche in terms of products, services and communication channels. The empirical data of our research are based on in-depth personal interviews held in the first half of 2007. Much information about the entrepreneurs was provided first from the Turkish 
businesses website "Webisrehberi" for the contact addresses, and then during the survey in an informal way using both the ethnic and business networks and personal contacts with entrepreneurs.

In the present section, we examine the profile of the Turkish entrepreneurs in the ICT and FIRE sectors in terms of personal characteristics, motivation, driving force, and entrepreneurial family tradition. An examination of the personal characteristics of Turkish entrepreneurs in the ICT and the FIRE sector, shows that the majority of the entrepreneurs (74 per cent) are aged between 30 and 49 . When the arrival year is taken into consideration, we see that more than half of the entrepreneurs (52 per cent) came to the Netherlands between 1971 and 1980 (when they were younger than 12 years old), whereas 22 percent were born in the Netherlands. Therefore, the majority (74 percent) of the entrepreneurs fall in the category of the second generation with their educational attainment (83 percent) achieved in the Netherlands. While the majority (56 per cent) graduated from middle and higher vocational schools, the rest (35 per cent) graduated from universities. Depending on their arrival year and educational attainment in the Netherlands, all of them can speak Dutch fluently or quite well, and most of them (83 per cent) can also speak English fluently or quite well. An overall evaluation of personal characteristics of the secondgeneration Turkish entrepreneurs draws attention to their higher educational level and language ability (see Table 5).

\section{Table 5 about here}

When we look at the labour market position, the previous experience, and the previous sector of Turkish entrepreneurs before the start of their present business (Table 5), we see that the majority (78 per cent) of the entrepreneurs were employed, and 9 per cent were already active, as entrepreneurs in their previous labour market position. While, in general, unemployment is observed as a driving force to become entrepreneur for many immigrants, in our case unemployment was not found to be a driving force. On the contrary, it seems there is a pulling-effect to become an entrepreneur as a result of previous experience of being an entrepreneur through employment and/or entrepreneurship, and, moreover, the actual way that this experience was obtained as an employee and entrepreneur in the same sector (69 per cent). The sector choice of entrepreneurs also supports this pulling effect. Almost 40 per cent of the entrepreneurs moved into the ICT and FIRE sectors because of the high demand or a shortage of labour in the sectors, whereas another 40 per cent of the entrepreneurs have chosen their sectors because of their work experience, and 20 per cent because of their education. The current situation of the sector was evaluated by the majority of the entrepreneurs (52 per cent) as a growing sector, while emphasizing the existence of a great deal of changes, as well as intense competition in the sector. This growing and promising sector structure can be another pull-effect for entrepreneurs. The existence of Turkish entrepreneurs in the same sector does not show clear evidence of the attractiveness of these sectors for entrepreneurs: 48 percent of the entrepreneurs mentioned that the share of Turks in the sector is decreasing, while 30 per cent claimed, on the contrary, that the share of Turks is increasing. 
When we look at the reasons to become an entrepreneur, the first reason appears as 'to be independent' and 'to be one's own boss' (78 per cent). 'Flexibility' with a share of 13 per cent ranks as the second reason. It seems that to have an extra income is not an important reason to become an entrepreneur. While more than half of the entrepreneurs (52 per cent) have an entrepreneur family member, which could be evaluated as another motivation or driving force to become entrepreneur, the other factors such as capital sources and information sources show that entrepreneurs are not dependent on their family or friends. 74 per cent of the entrepreneurs have used their own capital and 61 per cent used their own experience (see Table 5). All these figures clearly show that the second-generation Turkish entrepreneurs are quite independent of their ethnic niche.

\subsection{Profile of Turkish enterprises in the ICT and the FIRE sectors}

In this section, we examine the profile of Turkish enterprises in the ICT and the FIRE sectors in terms of enterprise features, performance, profiles of employees and clients, and goals and strategies. Turkish enterprises in our case study are in two sectors: the ICT sector which consists of three groups of companies/entrepreneurs, viz. automation companies; software computer programming companies; and Internet service provider companies; and the FIRE sector which consists of finance, insurance, real estate, consulting, and accountancy companies (Table 6). However, the majority of the enterprises (70 per cent) in our sample are in the ICT sector. When we examine the features of the enterprises we observe that the second-generation Turkish entrepreneurship started after 1996, and there has been an enormous increase in start-up enterprises especially after 2000. More than half of the enterprises (57 per cent) in our sample started after 2000. Most of the enterprises are small, and the majority of them (61 per cent) have less than five workers.

\section{Table 6 about here}

When the development of sales and the profit of the previous year are examined for Turkish enterprises in the ICT and the FIRE sectors in terms of their performance, 91 per cent of the enterprises had an increase in sales, while the rest 9 per cent had about the same level (Table 6). The profit of the previous year shows the same success level: while 87 per cent of the entrepreneurs had a positive profit, 13 per cent had the same profit. There has been no decrease in the development of sales and no negative profit at all. These figures show a very high economic performance.

When we examine the number and the composition of employees, we see that 23 Turkish enterprises in the ICT and the FIRE sectors provide an employment opportunity for 111 persons, of whom 64 per cent are from their own ethnic group (Table 6). Although Turkish entrepreneurs have an independent profile on the basis of motivation and driving forces, as well as of capital and information sources, here interestingly we observe a relatively high dependency on the entrepreneurs' own ethnic

group in terms of hiring employees. While 22 per cent of the entrepreneurs explained that they needed to have Turkish employees because of their Turkish clients, 13 per cent clearly mentioned that they prefer 
Turkish employees for many other reasons. Nevertheless, more than half of the entrepreneurs (57 per cent) mentioned that they actually preferred to hire Dutch employees.

These figures show that the highest dependency on the entrepreneurs' own ethnic group, in comparison with all the other factors, is shown by the composition of employees. However, some of these figures can also be evaluated as a sign of transformation from the entrepreneurs' own ethnic group to other groups when hiring employees. On the other hand, when we examine the composition of the clients, we observe that 35 per cent of the enterprises have non-Turkish clients, while almost 40 per cent have a mixed clientele with a majority (80 per cent) of Turkish clients. Although the majority of the enterprises serve non-Turkish clients, the share of Turkish clients is quite high, and here we observe once more a dependency on the entrepreneurs' own ethnic group.

When we examine the target groups of the enterprises as a part of their goals and strategies, we again observe a relatively high dependency on clients from the entrepreneurs' own ethnic group. 35 per cent of the entrepreneurs indicated that their target group is Turks (Table 6). Another 35 per cent of the entrepreneurs mentioned that they had no target group, while 22 per cent mentioned that their target group was Dutch natives and other groups. On the other hand, the stated strategies of the majority (57 per cent) were to grow the business and to provide more products and services. Specialization was another strategy for 30 per cent of the enterprises.

An overall evaluation of the profile of Turkish entrepreneurs and enterprises in the ICT and the FIRE sectors shows that the second-generation Turkish entrepreneurship in the Netherlands started after 1996, and there has been an enormous increase in start-up enterprises especially after 2000. Depending on the arrival year of the Turkish immigrants in the Netherlands, we may expect this increase in start-up second-generation enterprises to continue in the future. We may also expect that the sector choice of the second generation Turkish entrepreneurs will be different from those of the first generation, and will probably be more oriented to non-traditional, new developing, and promising sectors, such as ICT, FIRE, or maybe the education and health sectors, where nowadays in many European countries immigrant employment is becoming increasingly significant (between 20 and 30 per cent of immigrants work in one of these two latter sectors in Finland, Switzerland, Sweden, and the UK (OECD, 2006)).

The results of our investigation demonstrate that the motivation and driving forces of the secondgeneration Turkish entrepreneurs stem from both their personal characteristics, shaped by their higher educational level and language ability, and their previous working experience as an employee or entrepreneur in the same sector. The demand for, and a shortage of labour in the sector, as well as the growing and promising structure of the sector, all seem to play an important role in pulling the secondgeneration Turkish immigrants to become entrepreneurs. In summary, we can say that the motivation and driving forces of the second-generation Turkish immigrants can be explained by the pull factors. While their main motivation to become entrepreneurs appears to be independent and flexible, the other reason could be that they possess an entrepreneurial spirit which comes from entrepreneurial family tradition, as more than half of the entrepreneurs have an entrepreneur family member. 
The results of our study show that the second-generation Turkish entrepreneurs are quite independent of their own ethnic group in terms of obtaining capital and information. They tend to use their own capital and own knowledge and experience, and when necessary they tend to apply to formal and financial institutions. We can say that their approach and behaviour is different from their first generation counterparts: it is more formal. This clearly shows that the second-generation Turkish entrepreneurs are quite independent of their ethnic niche. However, when the number and the composition of employees and clients are examined, this picture changes slightly. Although the second-generation Turkish entrepreneurs exhibit an independent profile on the basis of motivation and driving forces, as well as of capital and information sources, it is noticeable that there is still a relatively high dependency on their own ethnic group in terms of hiring employees and serving clients. Their relatively higher rate of having Turkish clients as a target group also highlights a relatively high dependency on clients from their own ethnic group. They adopt this strategy in order to benefit from both their own ethnic group and the other groups in the market. In any event, why would they wish to escape from potential and available clients from their own ethnic group? From this perspective, a relatively higher level of Turkish employees and clients cannot be seen as real ethnic dependency. On the contrary, this can be evaluated as a way of expanding the market and a transformation period from an internal orientation to an external orientation.

\section{Key Factors of Entrepreneurial Performance among Turkish Enterprises in the ICT and the FIRE Sector}

In this section, we will analyse in more detail the most prominent key factors of entrepreneurial performance among Turkish enterprises in the ICT and the FIRE sectors by using a multivariate qualitative classification method, called rough set analysis. First, in Section 5.1, we explain rough set analysis that originates from the artificial intelligence methodology. Then, in Section 5.2, we evaluate the empirical results of our rough set analysis that enable us to identify the new orientations in migrant entrepreneurship in terms of motivation, sectoral choice, goals, and strategies of second generation migrant entrepreneurs.

\subsection{Rough set analysis: an introduction}

Rough set theory developed by Pawlak (1991) has emerged as a major mathematical method to manage uncertainties from inexact, noisy and incomplete information. The applications of rough set theory to solving specific complex problems have been an attractive research topic in recent years and a large number of rough set theory applications have been reported in various fields such as medicine, economics, finance, business, environmental engineering, intelligent control, signal and image analysis, software engineering, decision analysis, social sciences, molecular biology and pharmacy (for a comprehensive review of the available literature on applications of rough set theory, see Wu and Zhang, 2004). Rough set theory is an extension of set theory; it can effectively handle discrete variables with multilevel categories. A rough set provides a representation of a given set using lower and upper 
approximations when the available information is not sufficient for determining the exact value of the set. The main objective of rough set analysis is to synthesize the approximation of concepts from the acquired data. It is non-parametric and, instead of null hypothesis of significance testing, rough set theory provides an alternative way to evaluate the importance of factors. Furthermore, rough set theory can classify cases into groups with similar properties by considering multiple dimensions that help reduce the unobserved heterogeneity.

Rough set data analysis (RSDA) is a classification method for the analysis and classification of non-stochastic (including qualitative and nominal) information. RSDA is an application of Knowledge Discovery in Databases which is concerned with extracting useful information from a complex multivariate database (Fayyad et al., 1996). The rough set methodology for knowledge discovery provides a powerful tool for knowledge discovery from a large and incomplete data set. The purpose of RSDA is to find models that describe or classify measurement data. This task falls into an extensive category of pattern recognition, which, broadly speaking, can be said to be the science of constructing models that describe or classify measurements. RSDA is based on minimal model assumptions in terms of formal causal specifications and admits ignorance when no proper conclusion can be drawn from the data at hand (Ziarco, 1998). Hence, it is more exploratory and heuristic in nature, and aims to generate conditional statements on classified data.

RSDA draws all its information from the a priori given data set. In RSDA, there is no numerical system that is different from the operationalization of the observed data, and there are no outside parameters to be chosen, nor is there any deductive statistical model to be fitted. RSDA can be viewed as a preprocessing device to recognize the potentially important explanatory variables. Data reduction is the main feature of RSDA, as it allows us to represent hidden structures in the database. The final outcome of the database is a decision table from which decision rules can be inferred by using rough set analysis. The rules are logical statements (if...then), which represent the relationship between the description of objects and their assignment to particular classes (see Pawlak, 1991, 1992). Details on RSA both from a methodological and from an applied perspective can, inter alia, be found in Degoun et al. (1997), Famili et al. (1997), Fayyad et al. (1996), Pawlak (1991, 1992), Slowinski (19950, van den Bergh et al. (1998), Wu and Zhang (2004) and Ziarco, (1998). The reader is referred to these studies for more details.

The RSA in our study is carried out with the help of the computer program Rough Set Data Explorer (ROSE). We use the ROSE software here to identify the new orientations in migrant entrepreneurship in terms of motivation, sectoral choice, goals and strategies. Rough set theory allows us to analyse the new orientations in multiple dimensions and to highlight the most prominent factors behind the new sectors: in our case, the ICT and FIRE sectors, and the sectoral choice of migrant entrepreneurs. In our study, the data system on Turkish entrepreneurs in the ICT and FIRE sectors is often of a categorical nature, for instance, nominal data (e.g. generation, education, etc.) or ordinal (e.g. rank order data on age categories, etc.), and therefore it is suitable for classification and explanation. RSA acts then as a specific multidimensional classification approach that appears to be able to identify various important 
factors in the orientation of migrant entrepreneurs. In the next sub-section, we will describe in some more detail the database used in our study.

\subsection{Results of rough set analysis}

The application of RSA proceeds in two successive steps; (i) the construction of an information survey; and (ii) the classification of information contained in the survey. In our case, the information survey consists of the entrepreneurial characteristics of migrant entrepreneurs in terms of their motivation and orientation (Table 7). As can be seen in Table 7, our rough set framework consists of 17 variables under three categories viz. personal characteristics (e.g. age, generation, education level), motivation and driving forces (e.g. position before start, previous experience, entrepreneur family member), and orientation (e.g. nationality of employees, nationality of clients, target group). In our rough set framework, we used all variables as conditional attributes and two variables including A8(D2) sectoral choice and A17(D1) the sectors as decision attributes as well. Therefore, we used RSA separately for both the sectors and sectoral choice as decision variables to highlight the characteristics of the sectors (ICT and FIRE) investigated and the factors which determine sectoral choice and orientation of migrant entrepreneurs.

\section{Table 7 about here}

The next step, the classification of information contained in the survey, is one of the most problematic issues in the application of RSA, as the chosen thresholds are not always unambiguous, and hence may also lead to information loss. In general, some sensitivity analysis on the classification used is meaningful, as a balance needs to be found between homogeneity and class size. In our case, after some sensitivity analyses, the categories for each relevant attribute were defined and listed (see Table 7). Next, on the basis of these categories, the resulting coded information table was constructed for Turkish entrepreneurs in the ICT and FIRE sectors (see Table 8).

\section{Table 8 about here}

In the technical application of RSA, three main sets of indicators and outputs, viz. (i) the reducts and the core; (ii) the lower and the upper approximation; and (iii) rules, can then be calculated.

1. The reduct - in other words, a minimal set of attributes - is the minimal subset which ensures the same quality of classification as the set of all attributes. The intersection of all reducts/minimal subsets (in other words, an attribute that appears in all minimal sets) is defined as the core. The core is a collection of the most significant attributes for the classification in the system. For our data set, no core attribute was found, and with a limitation on the number - in order to get the most concise results - ten sets of reducts were found for the sectors and sectoral choice of migrant entrepreneurs. The reducts for 
each set of data on the basis of the decision variable for the sectors and sectoral choice are given in Table 9. Next, the relative frequencies of appearance of the condition attributes in the reducts for each data set are given in Table 10.

\section{Table 9 about here}

\section{Table 10 about here}

When we examine the relative frequencies of appearance of the condition attributes in reducts for type of sector and sectoral choice, the results show that three factors/attributes, viz. A13 (nationality of employees), $A 14$ (preferences for employees) and A16 (target group) appear as relatively important attributes with higher frequency rates. This means that these attributes strongly influence the sector structure and sectoral choice of Turkish entrepreneurs.

2. The lower and upper approximation - and derived accuracy of relationships for each value class of the decisional variable - is another indicator from an RSA. The accuracy of the classification is the lower divided by the upper approximation of each class. Accuracy and quality of classification can also be derived from the choice of thresholds. Accuracy and quality of the classification for the sectors and sectoral choice are given in Table 11. For all classes of sector and sectoral choice, the accuracy appears to be 1 . Also the accuracy and quality of classification are equal to 1 . This value is the maximum value in all these cases. This means that, on the basis of the chosen sector and sectoral choice, the variables in our sample are fully discernible regarding the classes of decision variables.

\section{Table 11 about here}

3. The rules - exact or approximate relationships between explanatory variables and dependent variables - offer the possibilities to extract conditional causal structures from our data set. Decision rules are conditional statements that are expressed in the form of "if-then" statements. A rule may be exact or approximate. An exact rule (or deterministic) guarantees that a particular combination of categories of the condition attributes results in only one particular category of the decision attribute (same conditions, same decisions). An approximate rule (or non-deterministic), on the other hand, states that a particular combination of categories of the condition attributes corresponds to more than one category of the decision attribute (same conditions, different decisions). Therefore, only in the case of exact rules, using the information contained in the decision table, is it always possible to state with certainty whether an object belongs to a certain class of the decision variable. The quality of the decision rule is indicated by its strength. The strength of a rule represents the number of observations or cases that are in accordance with that rule. Table 12 shows the rules and their strengths that can be generated from our data set for Turkish entrepreneurs. We only use the rules with strength of 3 or more. This means that the relation described in the rule appears at least three times in the data set, but in some cases it also appears eight or nine times. Therefore, we selected the most significant rules that have a higher strength, which means 
the number of cases matching the rule. This information enables us to classify the important factors behind the orientation and sectoral choice of migrant entrepreneurs.

\section{Table 12 about here}

Table 13 describes the significant rules and the most important factors behind the orientation and sectoral choice of Turkish entrepreneurs. The results of the RSA show that "working experience as an employee in the same sector" and "educational attainment" lead the second-generation Turkish entrepreneurs to orient towards the ICT sector, while "a perceived demand for the sector", "the increasing number of Turks in the sector", and "potential Turkish clients" attract the second-generation Turkish entrepreneurs to the FIRE sector. "Age" appears as another important factor in the ICT sector, while relatively older entrepreneurs are motivated by their own experience, the youngest entrepreneurs are more motivated by an entrepreneurial family tradition.

The results of the RSA also show that, "entrepreneurial experience in a different sector", "own information and experience", and "Turkish clients" appear as important factors in perceiving a shortage of labour in, or a demand for, the sectors and determine the sectoral choice on the basis of demand, while "educational opportunities in the Netherlands", "higher educational level", "experience as employed", and, related to this educational background, having "preferences for Dutch employees" constitute the main factors behind a sectoral choice on the basis of education and experience. This educational and working experience lead Turkish entrepreneurs to be active in the ICT sector.

\section{Table 13 about here}

The most important factors underlying motivation, driving forces, and sectoral choice of the second-generation Turkish entrepreneurs in the ICT and FIRE sectors in the Netherlands turned out to be the following three factors/attributes: (i) nationality of employees; (ii) preferences for employees, and (iii) target group (see Table 14). However, our evaluation clearly shows that there are some differences in orientation to the ICT and, to the FIRE sectors. The existence of both Turkish entrepreneurs in the sector and potential Turkish clients, and as a result a perceived demand for the sector, constitute the determining factors behind the choice for the FIRE sector, while educational attainment and working experience appear as determining factors in orientation to the ICT sector (see Table 15).

\section{Table 14 about here}

Table 15 about here

\section{Retrospect and Prospect}


A growing number of the second-generation migrant entrepreneurs and an orientation to nontraditional sectors have become the new trends in migrant entrepreneurship in recent years. The second generation have contributed to the emergence of new areas of immigrant business activity such as ICT and the creative industries. Similar trends, a sectoral change in immigrant entrepreneurship especially towards to producer services, and an increasing number of second-generation immigrant entrepreneurs in these sectors, are also observed in the Netherlands.

Our study investigated the new - external - orientations in migrant entrepreneurship in terms of motivation, sectoral choice, goals, and strategies of the second-generation migrant entrepreneurs, by addressing the second-generation Turkish entrepreneurs in the ICT and the FIRE sectors in the Netherlands. The results of our investigation show that a new orientation to the non-traditional sector or, in other words, an external orientation combined with personal characteristics, skills, and experience may produce a very high economic performance and degree of success for the second-generation Turkish entrepreneurs. Therefore, this new orientation may also help them to escape from the ethnic enclave and break away from their ethnic dependency. Moreover, this external orientation may also help them to expand their market. However, this external orientation does not mean that they will not also continue to benefit from their own ethnic group. The results of our study show that the motivation and driving forces of the second-generation Turkish entrepreneurs stem from both their personal characteristics shaped by their higher educational level and their previous working experience as employees or entrepreneurs in the same sector. The demand for, and a shortage of labour, in the sectors, as well as their growing and promising structure also play an important role in pulling the second-generation Turkish immigrants to become entrepreneurs in these new sectors.

The results of our study by means of rough set analysis (RSA) show that the most important factors underlying motivation, driving forces and sectoral choice of the second generation Turkish entrepreneurs in the ICT and FIRE sectors in the Netherlands turned out to be the flowing three factors/attributes:

- Nationality of employees;

- Preferences for employees;

- Target group.

The results of the RSA show that there are also some differences in orientation to the ICT and the FIRE sectors. Educational attainment and working experience appear as determining factors in orientation to the ICT sector, while the existence of both Turkish entrepreneurs in the sector and potential Turkish clients, and as a result a perceived demand for the sector, constitute the determining factors behind the choice for the FIRE sector. An overall evaluation shows that Turkish entrepreneurs in the ICT sector show a more independent attitude than those in the FIRE sector. The FIRE sector seems to be more dependent on ethnic market and ethnic niche. However, the general results of our study indicate that the secondgeneration Turkish entrepreneurs in the Netherlands have started to move into new and non-traditional sectors like the ICT and FIRE sectors, instead of staying in the traditional hospitality sector which has been, and still is, popular among Turkish entrepreneurs. 


\section{References}

Aghion, P. (2002) 'Schumpeterian Growth Theory and the Dynamics of Income Inequality', Econometrica, 70(3): 855-882.

Audretsch, D.B., Thurik, A.R. (2001) 'What's New about the New Economy? Sources of Growth in the Managed and Entrepreneurial Economies', Industrial and Corporate Change, 1(10): 267-315.

Baycan-Levent, T., Masurel, E., Nijkamp, P. (2003) 'Diversity in Entrepreneurship: Ethnic and Female Roles in Urban Economic Life', International Journal of Social Economics, 30(11-12): 1131-1161.

Baycan-Levent, T., Masurel, E., Nijkamp, P. (2006) ‘Gender Differences in Ethnic Entrepreneurship', International Journal of Entrepreneurship and Innovation Management, 6(3): 173-190.

Bergh, J.C.J.M. van den, Button, K., Nijkamp, P., Pepping, G. (1998) Meta-analysis in Environmental Economics. Dordrecht: Kluwer.

Bergh, J.C.J.M. van den, Faber, A., Idenburg, A.M., Oosterhuis, F.J. (2007) Evolutionary Economics and Environmental Policy: Survival of the Greenest. Cheltenham: Edward Elgar.

Bijl, R.V., Zorlu, A., Rijn, A.S. van, Jeenissen, R.P.W., Blom, M. (2005) The Integration Monitor 2005: The social integration of migrants monitored over time: trend and cohort analyses. Ministry of Justice Research and Documentation Centre and Statistics Netherlands.

Boschma, R.A., Lambooy, J.G. (2001) 'Evolutionary economics and regional policy', The Annals of Regional Science, 35(1): 113-131.

Brücker, H., Epstein, G.S., McCormick, B., Saint-Paul, G., Venturini, A., Zimmermann, K. (2002) 'Managing migration in the European welfare state', in T. Boeri, G. Hanson and B. McCormick. (eds) Immigration policy and the welfare system. Oxford: OUP.

Centraal Bureau voor de Statistiek (CBS) (2007) http://www.cbs.nl

Choenni, A. (1997) Veelsoortig Assortiment. Amsterdam: Het Spinhuis.

Cooper, R.S. (2003) 'Purpose and Performance of the Small Business Innovation Research (SBIR) Program', Small Business Economics, 20(2): 137-151.

Dagevos, J., M. Gesthuizen (2005) Niet-westerse allochtonen met een stabiele arbeidsmarktpositie: aantallen en ontwikkelingen. SCP: Sociaal en Cultureel Planbureau, Den Haag, November 2005.

Dagevos, J., Gijsberts, M., van Praag, C. (2003) Rapportage minderheden 2003: onderwijs, arbeid en sociaal-culturele integratie. Den Haag: SCP.

Dana, L. -P. (ed.) (2007) 'Handbook of Research on Ethnic Minority Entrepreneurship, Edward Elgar, Cheltenham.

Deogun J., Raghavan, V., Sarkar, A., Sever, H. (1997) 'Data Mining: Trends in Research and Development', in T.Y. Lin and N. Cercone (eds) Rough Sets and Data Mining. Analysis for Imprecise Data. Dordrecht: Kluwer, 4-46.

Dieleman, F. (1993) 'Multicultural Holland: Myth or Reality?', in R. King (ed.) Mass Migrations in Europe: The Legacy and the Future. London: Belhaven Press, 118-135.

EIM (2004) Monitor Etnisch Ondernemerschap 2004. Onderzoek voor Bedrijf \& Beleid, Zoetermeer: Ministerie van Economische Zaken, November 2004.

Euwals, R., Dagevos, J., Gijsberts M., Roodenburg, H. (2007) Immigration, Integration and the Labour Market: Turkish Immigrants in Germany and the Netherlands. Discussion Paper Series, IZA DP No. 2677.

Famili A., Shen, W.M., Weber, R., Simoudis, E. (1997) 'Data Preprocessing and Intelligent Data Analysis', Intelligent Data Analysis, 1(1): 33-47.

Fayyad, U., Piatetsky-Shapiro, G., Smyth, P. (1996) 'From Data Mining to Knowledge Discovery: An Overview', Artificial Intelligence Magazine, 17: 37-54.

Fujita, M., Krugman, P. (2004) 'The New Economic Geography: Past, Present and the Future', in Florax, R.J.G.M. and Plane, D. (eds) Fifty Years of Regional Science. Heidelberg: Springer.

Garssen, J., Zorlu, A. (2005) 'Demografie', in Jaarrapport Integratie 2005. Voorburg: Den Haag, SCP/ WODC / CBS, 14-27.

Groot, H.L.F. de, Nijkamp, P., Stough, R. (2004) Entrepreneurship and Regional Economic Development: A Spatial Perspective. Cheltenham: Edward Elgar.

Hartog, J., Vriend, N. (1990) 'Young Mediterraneans in the Dutch labour market: A Comparative Analysis of Allocation and Earnings', Oxford Economic Papers, 42: 379-401.

Hébert, R.F., Link, A.N. (1989) 'In Search of the Meaning of Entrepreneurship', Small Business Economics, 1: 39-49. 
Hofstede, G. (1991) Cultures and Organizations: Software of the Mind. London: McGraw-Hill.

Houtzager, D., Rodrigues, P.R. (2002) Migrants, Minorities and Employment in the Netherlands; Exclusion, Discrimination and Anti-discrimination. Raxen 3 Report to the European Monitoring Centre on Racism and Xenophobia (EUMC).

lyigun, M.F., Owen, A.L. (1998) 'Risk, Entrepreneurship and Human-capital Accumulation', American Economic Review, 88(2): 454-457.

Jacobs, J. (1961) The Life and Death of Great American Cities. New York: Random House.

Jansen, M., Kok, J. de, Spronsen, J., Willemsen, S. (2003) Immigrant Entrepreneurship in the Netherlands -Demographic Determinants of Entrepreneurship of Immigrants from Non-Western Countries'Scales. Zoetermeer.

Jones, T., Ram, M. (2007), Re-embedding the Ethnic Business Agenda, Work, Employment and Society, 21(3): 439-457.

Kaa, D.J., van de (1996) 'International mass migration: A threat to Europe's borders and stability?' $D e$ Economist, 144(2):

Kamer van Koophandel (2006) www.kvk.nl

Kassichieh, S.K., Kirchhoff, B.A., Walsh, S.T., McWorter, P.J. (2002) 'The Role of Small Firms in the Transfer of Disruptive Technologies', Technovation, 22: 667-674.

Kleinknecht, R.A. (1982) 'The origins and remission of fear in a group of tarantula enthusiasts', Behaviour Research and Therapy, 20: 437-443.

Kloosterman, R.C., Rath, J. (2001) 'Immigrant Entrepreneurs in Advanced Economics, Journal of Ethnic and Migration Studies, 27(2): 189-201.

Kraal, K., Zorlu, A. (1998) City Template Amsterdam. Basic Information on Ethnic Minorities and Their Participation. Report According to the Grid for City Templates of the MPMC Project, Amsterdam: IMES.

Leydesdorff, L., Etzkowitz, H. (1998) 'The Triple Helix as a Model for Innovation Studies (Conference Report)', Science \& Public Policy, 25(3): 195-203.

Lucas R.E. (1988) 'On the Mechanics of Economic Development', Journal of Monetary Economics, 22(1): 3-42.

Lucassen, L., Penninx, R. (1997) Newcomers. Immigrants and their Descendants in the Netherlands 1550-1995. Amsterdam: Het Spinhuis (published originally in Dutch in 1994: Nieuwkomers, Nakomelingen, Nederlanders).

Lumpkin, G.T., Dess, G.G. (1996) 'Clarifying the Entrepreneurial Orientation and Linking it to Performance', Academy of Management Review, 21: 135-152.

Malecki, E.J. (1997) Technology \& Economic Development: The Dynamics of Local Regional and National Competitiveness. Harlow: Addison Wesley Longman.

Markusen, A. (1996) 'Sticky spaces in slippery space: A typology of industrial districts', Economic Geography, 72: 293-313.

Masurel, E., Nijkamp, P. (2004) 'Differences between first-generation and second-generation ethnic startups: Implications for a new support policy', Environment and Planning C: Government and Policy; 22(5): 721-737.

Nelson, R., Winter, S. (1982) An Evolutionary Theory of Economic Change. Cambridge, MA: Belknap Press of Harvard University.

Nijkamp, P., Poot, J. (1998) 'Spatial perspectives on new theories of economic growth', Annals of Regional Science, 32(1): 7-37.

Oort, F.J. van, Atzema, O.A.L.C. (2004) 'On the Conceptualization of Agglomeration Economics: The Case of New Firm Formation in the Dutch ICT Sector', Annals of Regional Science, 38: 263-290.

OECD (2006) International Migration Outlook. SOPEMI 2006 Edition, OECD, Paris.

Pawlak, Z. (1991) Rough Sets. Dordrecht: Kluwer.

Pawlak, Z. (1992) 'Rough Sets: Introduction', in R. Slowinski (ed.) Intelligent Decision Support - Handbook of Applications and Advances of the Rough Set Theory. Dordrecht: Kluwer,1-2.

Piore, M.J., Sabel, C.F. (1984) 'The Second Industrial Divide', in Possibilities for Prosperity. New York: Basic Books.

Poot, J. (2007) Demographic Change and Regional Competitiveness: The Effects of Immigration and Ageing. Population Studies Centre, Discussion Papers, No. 64.

Rath, J. (ed.) (2000), Immigrant Business, MacMillan, Baringstoke.

Romer, P.M. (1990) 'Endogenous Technological Change', Journal of Political Economy, 98(5): S71-S102. 
Rusinovic, K. (2006) Dynamic Entrepreneurship: First and second-generation immigrant entrepreneurs in Dutch cities. IMISCOE Dissertations, Amsterdam University Press.

Schumpeter, J. A. (1957) Economic Doctrine and Method. London: Allen \& Unwin.

Slowinski, R. (1995) Intelligent Decision Support: Handbook of Applications and Advances of Rough Set Theory. Dordrecht: Kluwer. Sociaal Cultureel Planbureau (SCP)/LAS (2004/2005).

Stiles, C., Galbraith, C. (eds.) (2004), Ethnic Entrepreneurship, Elsevier, Oxford.

Tillie, J., Slijper, B. (2006) 'Immigrant political integration and ethnic civic communities in Amsterdam', in S. Benhabib and I. Shapiro (eds) Identities, Affiliations, and Allegiances. Cambridge University Press.

Waldinger, R., Aldrich, H., Ward, R. (eds) (1990) Ethnic Entrepreneurs. Newbury Park, CA.: Sage Publishers.

Ward, R., Jenkins, R. (eds) (1984) Ethnic Communities in Business. Cambridge: Cambridge University Press.

Wennekers, S., Thurik, A.R. (1999) 'Linking entrepreneurship and economic growth', Small Business Economics, 13(1): 27-55.

Wu, W., Zhang, W. (2004) 'Constructive and axiomatic approaches of fuzzy approximation operators', Information Sciences, 159(3-4): 233-254.

Ziarco, W. (1998) 'Rough Set as a Methodology for Data Mining', in A. Skowron and L. Polkowski (eds) Rough Set in Knowledge Discovering. Heidelberg: Physica Verlag, 554-576.

Zorlu, A., Hartog, J. (2001) Migration and Immigrants: The case of the Netherlands. Paper prepared for Migration Policy and the Economy: International Experiences, Munchen: Hans Seidel Stiftung.

Zorlu, A., Traag, T. (2005) 'Opleidingsniveau en taalvaardigheid, in Jaarrapport Integratie 2005. Den Haag, Voorburg: SCP / WODC / CBS, 44-56. 


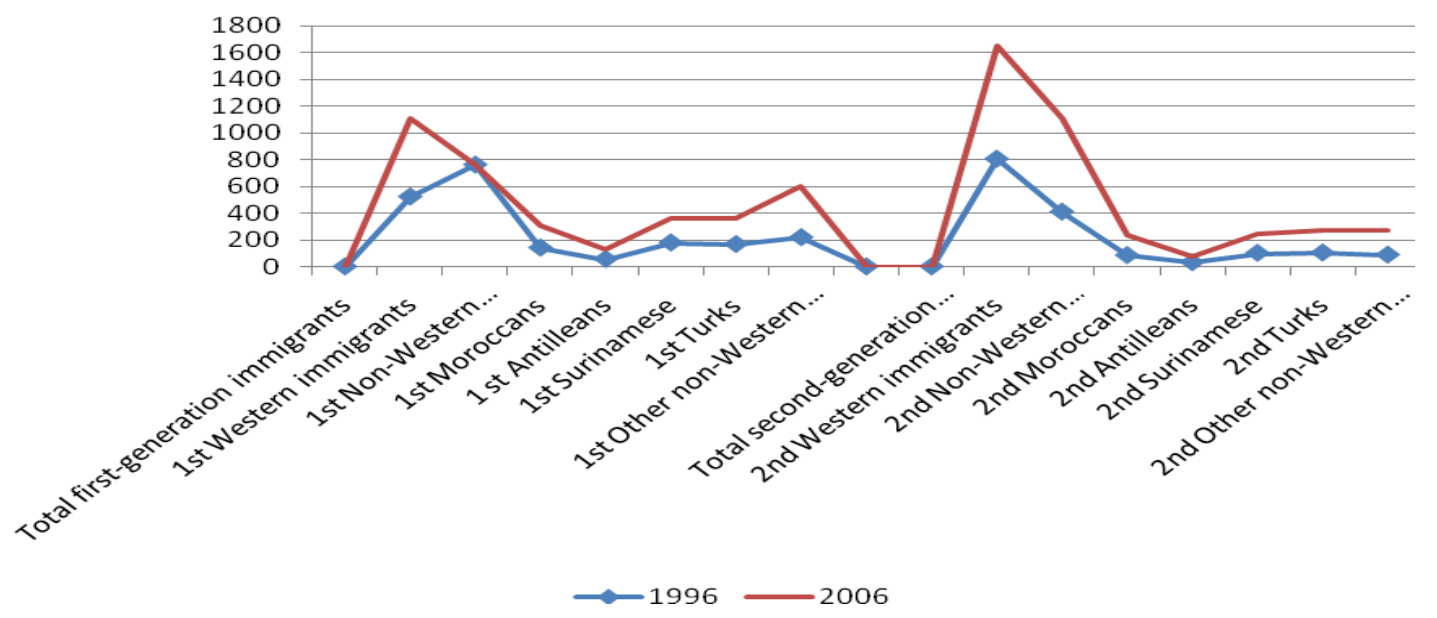

Figure 1 Demographic development of Dutch immigrant population 1996-2006 (CBS, 2007)

Table 1 Development of the number of entrepreneurs in the Netherlands, 1999-2004

\begin{tabular}{lllcccc}
\hline \hline Year & $\begin{array}{l}\text { Native } \\
\text { entrepreneurs }\end{array}$ & $\begin{array}{l}\text { Western } \\
\text { immigrants } \\
\text { entrepreneurs }\end{array}$ & $\begin{array}{c}\text { Non-Western immigrant entrepreneurs } \\
\mathbf{1}^{\text {st }}\end{array}$ & $\begin{array}{c}\mathbf{2}^{\text {nd }} \\
\text { generation }\end{array}$ & $\begin{array}{c}\mathbf{1}^{\text {st }} \text { and 2 } \\
\text { generation }\end{array}$ & generation \\
\hline $\mathbf{1 9 9 9}$ & 819,000 & 72,700 & 30,200 & 3,900 & 34,100 & 925,800 \\
$\mathbf{2 0 0 0}$ & 835,400 & 75,000 & 33,700 & 4,700 & 38,400 & 948,806 \\
$\mathbf{2 0 0 1}$ & 845,100 & 77,200 & 38,100 & 5,500 & 43,600 & 965,900 \\
$\mathbf{2 0 0 2}$ & 841,400 & 77,200 & 39,500 & 6,000 & 45,500 & 964,100 \\
$\mathbf{2 0 0 3}$ & 842,300 & 77,300 & 40,700 & 6,400 & 47,100 & 966,799 \\
$\mathbf{2 0 0 4}$ & 818,300 & 74,500 & 40,100 & 6,800 & 46,900 & 939,799 \\
\hline
\end{tabular}

Source: CBS, 2007.

Table 2 Number of entrepreneurs $(\times 1,000)^{*}, 1999-2004$

\begin{tabular}{lcccc}
\hline Year & Turkey & Morocco & $\begin{array}{c}\text { Netherlands/ } \\
\text { Antilles }\end{array}$ & Surinam \\
\hline $\mathbf{1 9 9 9}$ & & 2.8 & 1.5 & 6.4 \\
$\mathbf{2 0 0 0}$ & 7.9 & 3.3 & 1.8 & 7.1 \\
$\mathbf{2 0 0 1}$ & 9.2 & 4.0 & 2.0 & 7.8 \\
$\mathbf{2 0 0 2}$ & 11.0 & 4.3 & 2.1 & 7.9 \\
$\mathbf{2 0 0 3}$ & 11.5 & 4.4 & 2.2 & 8.0 \\
$\mathbf{2 0 0 4}$ & 11.9 & 4.6 & 2.1 & 7.7 \\
\end{tabular}

Source: CBS (2007).

Note: This table includes both first- and second-generation immigrant entrepreneurs. 
Table 3 Sectoral distribution among first- and second-generation non-Western immigrant entrepreneurs, 1999-2002 (in percentages)

\begin{tabular}{lrrrr}
\hline \hline & \multicolumn{2}{c}{ First generation } & \multicolumn{2}{r}{ Second generation } \\
\hline & 1999 & 2002 & 1999 & 2002 \\
\hline Sector & & & & \\
Agriculture / fishing & 2 & 2 & 3 & 2 \\
Minerals / industry/ energy & 5 & 4 & 3 & 4 \\
Building industry & 3 & 5 & 6 & 7 \\
Trade and repair business & 26 & 25 & 22 & 21 \\
Hotel and catering industry & 35 & 31 & 14 & 12 \\
Transportation, storage and communication & 3 & 5 & 6 & 7 \\
Financial institutions & 1 & 1 & 3 & 2 \\
Producer services / business to business & 12 & 15 & 22 & 25 \\
Public administration / education & 3 & 3 & 3 & 2 \\
Health care and public welfare & 3 & 3 & 6 & 5 \\
Other services & 7 & 8 & 14 & 14 \\
& & & & \\
Total & 100 & 100 & 100 & 100 \\
\hline Source: & & & &
\end{tabular}

Source: EIM, 2004.

Table 4 Development of Turkish entrepreneurship in the Netherlands

\begin{tabular}{lrrrrrr}
\hline \hline & $\mathbf{1 9 9 9}$ & $\mathbf{2 0 0 0}$ & $\mathbf{2 0 0 1}$ & $\mathbf{2 0 0 2}$ & $\mathbf{2 0 0 3}$ & $\mathbf{2 0 0 4}$ \\
\hline First generation & 7,100 & 8,200 & 9,600 & 10,000 & 10,200 & 9,900 \\
Second generation & 800 & 1,000 & 1,300 & 1,500 & 1,700 & 1,800 \\
Total & 7,900 & 9,200 & 10,900 & 11,500 & 11,900 & 11,700 \\
\hline
\end{tabular}

Source: CBS (2007). 
Table 5 Profile of Turkish entrepreneurs in the ICT and the FIRE sectors

Personal characteristics

Age

$30-49$

74

Education

vocational (middle and higher) $\quad 56$

university

35

education place (NL)

language ability (Dutch)

83

83

Arrival year

born

22

1971-1980

52

Motivation and driving forces

Position before start

employed

78

entrepreneur

Previous sector

employee in the same sector

65 entrepreneur in the same sector employee in a different sector

Sector choice

GAP/big demand

experience

education

22

Situation of the sectors

growing/increasing

Turks in the sectors

growing/increasing

The reason to be entrepreneur

to be independent/to be own boss

Entrepreneur in the family

yes

52

Capital sources

own capital

74

Information sources

own experience

61 
Table 6 Profile of Turkish enterprises in the ICT and the FIRE sectors

\section{Business characteristics}

Activities of the enterprise

ICT sector

70

FIRE sector

Foundation year of the enterprise

1996-2000

39

$2001+$

Number of employees

$1-5$

Performance

Development of sales

increase

Profit last year

positive

Profile of employees and clients

Nationality of employees

$\begin{array}{ll}\text { Turkish employees } & 64\end{array}$

Preferences for employees

need for Turkish employees, because of Turkish clients 22 $\begin{array}{ll}\text { preference for Dutch native employees } & 57\end{array}$

Composition of clients $80 \%$ Turks - $20 \%$ Natives $\quad 39$ Non-Turkish clients

Goals and strategies

Target group

Turks

Dutch natives and other groups $\quad 22$ no target group 
Table 7 Classification of explanatory variables/attributes

\begin{tabular}{|c|c|c|}
\hline \multicolumn{3}{|c|}{ ATTRIBUTES* } \\
\hline $\begin{array}{l}\text { PERSONAL } \\
\text { CHARACTERISTICS }\end{array}$ & A7. Previous sector & ORIENTATION \\
\hline A1. Age & $1=$ Employee in the same sector & A13. Nationality of employees \\
\hline $1=20-29$ & 2 = Employee in a different sector & 1 = Only Turks \\
\hline $2=30-39$ & $3=$ Entrepreneur in the same sector & 2 = Only Dutch natives \\
\hline $3=40-49$ & 4 = Entrepreneur in a different sector & $3=$ More Turks than Dutch natives \\
\hline $4=50>$ & 5 = Student & $4=$ More Dutch natives than Turks \\
\hline A2. Generation & A8(D2). Sectoral choice & $5=$ Other \\
\hline $1=$ First generation & $1=\mathrm{GAP} /$ Big demand & \begin{tabular}{|l|} 
A14. Trust \\
\end{tabular} \\
\hline 2 = Second generation & $\begin{array}{l}2 \text { = Sufficient knowledge/info; work } \\
\text { experience }\end{array}$ & 1 = Need for Turkish employees \\
\hline A3. Education Level & 3 = Sufficient knowledge/info; education & $2=$ No Turkish employees at all \\
\hline 1 = Secondary education & A9. Situation of the sector & $3=$ Preference for Turkish employees \\
\hline $2=$ Middle vocational training & 1 = Growing/increasing & $\begin{array}{l}4 \text { = Preference for Dutch native } \\
\text { employees }\end{array}$ \\
\hline $3=$ High vocational training & 2 = Smaller/decreasing & A15. Nationality of clients \\
\hline 4 = University & $3=$ Changes a lot & 1 = Only Turks \\
\hline A4. Education Place & 4 = High competition & 2 = Only Dutch natives \\
\hline $1=$ The Netherlands & A10. Turks in the sector & $3=$ More Turks than Dutch natives \\
\hline 2 = Turkey & $1=$ Growing/increasing & $4=$ More Dutch natives than Turks \\
\hline $3=$ Other & 2 = Smaller/decreasing & $5=$ Other \\
\hline $\begin{array}{l}\text { MOTIVATION AND DRIVING } \\
\text { FORCES }\end{array}$ & $3=$ No idea & A16. Target group \\
\hline A5. Position before start & A11. Entrepreneur family member & $1=$ Yes, Turks \\
\hline 1 = Employed & $1=$ Yes & $\begin{array}{l}2=\text { Yes, Dutch natives and other } \\
\text { groups }\end{array}$ \\
\hline 2 = Unemployed & $2=\mathrm{No}$ & $3=$ Mixed \\
\hline $3=$ Entrepreneur & & $4=$ No \\
\hline 4 = Student & A12. Information sources & A17(D1). Sectors \\
\hline A6. Previous experience & $1=$ Own experience & $1=$ ICT sector \\
\hline 1 = Through employment & 2 = Relatives and family & 2 = FIRE sector \\
\hline $\begin{array}{l}2 \text { = Through entrepreneurship \& } \\
\text { employment }\end{array}$ & $\begin{array}{l}3=\text { Formal institutions and fellow } \\
\text { entrepreneurs }\end{array}$ & \\
\hline $3=$ Through school or study & $4=$ Combination of $1,2,3$ & \\
\hline
\end{tabular}

${ }^{*} \mathrm{~A}$ : condition attribute, $\mathrm{D}$ : decision attribute 
Table 8 Coded table for rough set analysis

\begin{tabular}{|c|c|c|c|c|c|c|c|c|c|c|c|c|c|c|c|c|c|}
\hline & \multicolumn{4}{|c|}{ Personal characteristics } & \multicolumn{8}{|c|}{ Motivation and driving forces } & \multicolumn{5}{|c|}{ Orientation } \\
\hline & $\mathbf{A 1}$ & $\mathbf{A 2}$ & A3 & A4 & A5 & A6 & A7 & $\begin{array}{c}\text { A8 } \\
\text { (D2) }\end{array}$ & A9 & $\mathbf{A 1 0}$ & A11 & A12 & $\overline{A 13}$ & $\overline{A 14}$ & A15 & $\mathbf{A 1 6}$ & $\begin{array}{l}\text { A17 } \\
\text { (D1) }\end{array}$ \\
\hline 1 & 4 & 1 & 3 & 1 & 3 & 2 & 3 & 1 & 1 & 2 & 1 & 1 & 3 & 1 & 3 & 3 & 1 \\
\hline 2 & 4 & 2 & 3 & 1 & 1 & 1 & 1 & 2 & 1 & 1 & 1 & 3 & 3 & 4 & 3 & 1 & 2 \\
\hline 3 & 1 & 2 & 4 & 1 & 4 & 3 & 4 & 1 & 1 & 1 & 2 & 1 & 2 & 2 & 3 & 1 & 2 \\
\hline 4 & 1 & 2 & 2 & 1 & 1 & 1 & 2 & 2 & 1 & 1 & 1 & 2 & 1 & 3 & 3 & 1 & 1 \\
\hline 5 & 3 & 2 & 3 & 1 & 1 & 1 & 1 & 1 & 1 & 1 & 1 & 1 & 1 & 1 & 3 & 1 & 2 \\
\hline 6 & 3 & 2 & 3 & 1 & 1 & 1 & 1 & 2 & 3 & 3 & 2 & 1 & 4 & 4 & 2 & 4 & 1 \\
\hline 7 & 2 & 1 & 4 & 2 & 1 & 1 & 1 & 2 & 1 & 3 & 1 & 2 & 1 & 4 & 3 & 1 & 1 \\
\hline 8 & 3 & 1 & 4 & 2 & 1 & 1 & 1 & 2 & 3 & 2 & 2 & 3 & 1 & 4 & 5 & 4 & 1 \\
\hline 9 & 1 & 2 & 1 & 3 & 1 & 1 & 4 & 1 & 4 & 2 & 1 & 1 & 3 & 4 & 4 & 4 & 1 \\
\hline 10 & 3 & 2 & 2 & 1 & 1 & 2 & 4 & 1 & 1 & 1 & 2 & 4 & 3 & 1 & 3 & 1 & 2 \\
\hline 11 & 2 & 2 & 3 & 1 & 1 & 2 & 1 & 2 & 4 & 2 & 1 & 1 & 1 & 4 & 4 & 4 & 1 \\
\hline 12 & 2 & 2 & 2 & 1 & 1 & 2 & 4 & 1 & 4 & 3 & 2 & 1 & 4 & 4 & 4 & 4 & 2 \\
\hline 13 & 2 & 2 & 4 & 1 & 4 & 3 & 5 & 2 & 1 & 3 & 1 & 1 & 4 & 4 & 2 & 4 & 1 \\
\hline 14 & 2 & 2 & 4 & 1 & 1 & 1 & 1 & 1 & 2 & 2 & 1 & 1 & 1 & 1 & 3 & 1 & 2 \\
\hline 15 & 3 & 2 & 1 & 1 & 1 & 1 & 1 & 2 & 2 & 2 & 2 & 1 & 1 & 3 & 2 & 2 & 1 \\
\hline 16 & 2 & 2 & 2 & 1 & 1 & 1 & 1 & 2 & 3 & 2 & 2 & 1 & 1 & 1 & 2 & 3 & 1 \\
\hline 17 & 3 & 2 & 2 & 1 & 1 & 1 & 1 & 2 & 3 & 2 & 2 & 1 & 1 & 4 & 4 & 2 & 1 \\
\hline 18 & 3 & 2 & 4 & 1 & 1 & 1 & 1 & 2 & 1 & 1 & 2 & 3 & 2 & 4 & 2 & 2 & 1 \\
\hline 19 & 2 & 2 & 4 & 1 & 4 & 3 & 5 & 2 & 4 & 3 & 1 & 4 & 2 & 4 & 5 & 4 & 1 \\
\hline 20 & 2 & 1 & 2 & 1 & 1 & 1 & 1 & 2 & 2 & 2 & 2 & 2 & 3 & 4 & 4 & 2 & 1 \\
\hline 21 & 2 & 1 & 3 & 1 & 1 & 1 & 1 & 2 & 1 & 2 & 1 & 1 & 5 & 4 & 4 & 2 & 1 \\
\hline 22 & 1 & 2 & 2 & 1 & 4 & 3 & 1 & 1 & 1 & 1 & 1 & 3 & 2 & 2 & 5 & 4 & 1 \\
\hline 23 & 2 & 1 & 4 & 2 & 1 & 1 & 1 & 1 & 1 & 2 & 2 & 1 & 1 & 3 & 3 & 1 & 1 \\
\hline
\end{tabular}

Table 9 Found reducts for sector and sectoral choice

\begin{tabular}{|r|l|r|l|}
\hline & Sector & & Sectoral Choice \\
\hline $\mathbf{1}$ & $\{\mathrm{A} 9, \mathrm{~A} 10, \mathrm{~A} 11, \mathrm{~A} 14\}$ & $\mathbf{1}$ & $\{\mathrm{A} 4, \mathrm{~A} 13, \mathrm{~A} 14, \mathrm{~A} 17\}$ \\
\hline $\mathbf{2}$ & $\{\mathrm{A} 4, \mathrm{~A} 8, \mathrm{~A} 14, \mathrm{~A} 16\}$ & $\mathbf{2}$ & $\{\mathrm{A} 9, \mathrm{~A} 10, \mathrm{~A} 13, \mathrm{~A} 14\}$ \\
\hline $\mathbf{3}$ & $\{\mathrm{A} 8, \mathrm{~A} 13, \mathrm{~A} 14, \mathrm{~A} 16\}$ & $\mathbf{3}$ & $\{\mathrm{A} 7, \mathrm{~A} 14, \mathrm{~A} 15\}$ \\
\hline $\mathbf{4}$ & $\{\mathrm{A} 9, \mathrm{~A} 13, \mathrm{~A} 14, \mathrm{~A} 16\}$ & $\mathbf{4}$ & $\{\mathrm{A} 10, \mathrm{~A} 13, \mathrm{~A} 14, \mathrm{~A} 15, \mathrm{~A} 16\}$ \\
\hline $\mathbf{5}$ & $\{\mathrm{A} 6, \mathrm{~A} 8, \mathrm{~A} 12, \mathrm{~A} 14, \mathrm{~A} 16\}$ & $\mathbf{5}$ & $\{\mathrm{A} 11, \mathrm{~A} 13, \mathrm{~A} 14, \mathrm{~A} 15\}$ \\
\hline $\mathbf{6}$ & $\{\mathrm{A} 3, \mathrm{~A} 14, \mathrm{~A} 16\}$ & $\mathbf{6}$ & $\{\mathrm{A} 12, \mathrm{~A} 13, \mathrm{~A} 15\}$ \\
\hline $\mathbf{7}$ & $\{\mathrm{A} 4, \mathrm{~A} 11, \mathrm{~A} 14, \mathrm{~A} 15, \mathrm{~A} 16\}$ & $\mathbf{7}$ & $\{\mathrm{A} 7, \mathrm{~A} 14, \mathrm{~A} 16\}$ \\
\hline $\mathbf{8}$ & $\{\mathrm{A} 10, \mathrm{~A} 14, \mathrm{~A} 15, \mathrm{~A} 16\}$ & $\mathbf{8}$ & $\{\mathrm{A} 10, \mathrm{~A} 13, \mathrm{~A} 14, \mathrm{~A} 16, \mathrm{~A} 17\}$ \\
\hline $\mathbf{9}$ & $\{\mathrm{A} 11, \mathrm{~A} 12, \mathrm{~A} 14, \mathrm{~A} 15, \mathrm{~A} 16\}$ & $\mathbf{9}$ & $\{\mathrm{A} 11, \mathrm{~A} 13, \mathrm{~A} 14, \mathrm{~A} 16, \mathrm{~A} 17\}$ \\
\hline $\mathbf{1 0}$ & $\{\mathrm{A} 13, \mathrm{~A} 14, \mathrm{~A} 15, \mathrm{~A} 16\}$ & $\mathbf{1 0}$ & $\{\mathrm{A} 12, \mathrm{~A} 13, \mathrm{~A} 16, \mathrm{~A} 17\}$ \\
\hline
\end{tabular}


Table 10 Frequency of attributes in reducts for ICT/FIRE sectors and sectoral choice

\begin{tabular}{|c|c|c|c|c|c|}
\hline \multicolumn{3}{|c|}{ Sector } & \multicolumn{3}{c|}{ Sectoral Choice } \\
\hline Attribute & $\begin{array}{c}\text { Frequency } \\
(\#)\end{array}$ & $\begin{array}{c}\text { Frequency } \\
(\%)\end{array}$ & Attribute & $\begin{array}{c}\text { Frequency } \\
(\#)\end{array}$ & $\begin{array}{c}\text { Frequency } \\
(\%)\end{array}$ \\
\hline A3 & 1 & 10 & A4 & 1 & 10 \\
\hline A4 & 2 & 20 & A7 & 2 & 20 \\
\hline A6 & 1 & 10 & A9 & 1 & 10 \\
\hline A8 & 3 & 30 & A10 & 3 & 30 \\
\hline A9 & 2 & 20 & A11 & 2 & 20 \\
\hline A10 & 2 & 20 & A12 & 2 & 20 \\
\hline A11 & 3 & 30 & A13 & $\mathbf{8}$ & $\mathbf{8 0}$ \\
\hline A12 & 2 & 20 & A14 & $\mathbf{8}$ & $\mathbf{8 0}$ \\
\hline A13 & 3 & 30 & A15 & 4 & 40 \\
\hline A14 & $\mathbf{1 0}$ & $\mathbf{1 0 0}$ & A16 & $\mathbf{5}$ & $\mathbf{5 0}$ \\
\hline A15 & 4 & $\mathbf{4 0}$ & A17 & 4 & 40 \\
\hline A16 & $\mathbf{9}$ & $\mathbf{9 0}$ & & & \\
\hline
\end{tabular}

Legend:

A3: $\quad$ Education level

A4: Education place

A6: $\quad$ Previous experience

A7: $\quad$ Previous sector

A8: Sectoral choice

A9: $\quad$ Situation of the sectors

A10: Turks in the sectors
A11: Entrepreneur family member

A12: Information sources

A13: Nationality of employees

A14: Preferences for employees

A15: Nationality of clients

A16: Target group

A17: Sectors

Table 11 Accuracy and quality of the classification for ICT/FIRE sectors and sectoral choice

\begin{tabular}{|c|c|c|c|}
\hline \multicolumn{4}{|l|}{ ICT/FIRE sectors } \\
\hline Class & Accuracy & Lower approximation & Upper approximation \\
\hline ICT & 1 & 17 & 17 \\
\hline FIRE & 1 & 6 & 6 \\
\hline \multicolumn{2}{|l|}{ Accuracy of classification: } & \multicolumn{2}{|l|}{1} \\
\hline \multicolumn{2}{|l|}{ Quality of classification: } & \multicolumn{2}{|l|}{1} \\
\hline \multicolumn{4}{|l|}{ Sectoral Choice } \\
\hline Class & Accuracy & Lower approximation & Upper approximation \\
\hline Demand & 1 & 9 & 9 \\
\hline Education\&Experience & 1 & 14 & 14 \\
\hline \multicolumn{2}{|l|}{ Accuracy of classification: } & \multicolumn{2}{|l|}{1} \\
\hline \multicolumn{2}{|l|}{ Quality of classification: } & \multicolumn{2}{|l|}{1} \\
\hline
\end{tabular}


Table 12 Rules generated by the rough set analysis for ICT/FIRE sectors and sectoral choice

\begin{tabular}{|c|c|c|c|}
\hline Rules & Description of rules & $\begin{array}{l}\text { Strength } \\
(\#)\end{array}$ & $\begin{array}{c}\text { Strength } \\
\text { (\%) }\end{array}$ \\
\hline \multicolumn{4}{|c|}{ ICT/FIRE sectors } \\
\hline rule 1 & $(\mathrm{~A} 7=1) \&(\mathrm{~A} 11=2) \Rightarrow(\mathrm{D} 1=\mathbf{1})$ & 8 & 47.06 \\
\hline rule 2 & $(\mathrm{~A} 1=2) \&(\mathrm{~A} 8=2)=>(\mathrm{D} 1=\mathbf{1})$ & 7 & 41.18 \\
\hline rule 3 & $(\mathrm{~A} 1=1) \&(\mathrm{~A} 11=1) \Rightarrow(\mathrm{D} 1=1)$ & 3 & 17.65 \\
\hline rule 4 & $(A 8=1) \&(A 10=1) \&(A 15=3) \Rightarrow(D 1=2)$ & 3 & 50.00 \\
\hline rule 5 & $(\mathrm{~A} 4=1) \&(\mathrm{~A} 7=1) \&(\mathrm{~A} 15=3)=>(\mathrm{D} 1=2)$ & 3 & 50.00 \\
\hline \multicolumn{4}{|c|}{ Sectoral Choice } \\
\hline rule 1 & $(\mathrm{~A} 12=1) \&(\mathrm{~A} 15=3)=>(\mathrm{D} 2=1)$ & 5 & 55.56 \\
\hline rule 2 & $(\mathrm{~A} 7=4)=>(\mathrm{D} 2=\mathbf{1})$ & 4 & 44.44 \\
\hline rule 3 & $(\mathrm{~A} 4=1) \&(\mathrm{~A} 5=1) \&(\mathrm{~A} 17=1)=>(\mathrm{D} 2=2)$ & 9 & 64.29 \\
\hline rule 4 & $(A 3=4) \&(A 14=4)=>(D 2=2)$ & 5 & 35.71 \\
\hline
\end{tabular}

Table 13 Description of significant rules and the most important factors behind orientation and sectoral choice of Turkish entrepreneurs

\begin{tabular}{|c|c|c|c|c|c|c|}
\hline RULES & IF & & & & & THEN \\
\hline \multicolumn{7}{|c|}{ ICT/FIRE sectors } \\
\hline Rule 1 & $\begin{array}{c}\text { previous sector: } \\
\text { employee in the same sector }\end{array}$ & + & $\begin{array}{l}\text { entrepreneur family: } \\
\text { no }\end{array}$ & & & $\begin{array}{l}\text { sector: } \\
\text { ICT }\end{array}$ \\
\hline Rule 2 & $\begin{array}{l}\text { age: } \\
30-39\end{array}$ & + & $\begin{array}{c}\text { sectoral choice: } \\
\text { education \& experience }\end{array}$ & & & $\begin{array}{l}\text { sector: } \\
\text { ICT }\end{array}$ \\
\hline Rule 3 & $\begin{array}{l}\text { age: } \\
20-29\end{array}$ & + & $\begin{array}{l}\text { entrepreneur family: } \\
\text { yes }\end{array}$ & & & $\begin{array}{l}\text { sector: } \\
\text { ICT }\end{array}$ \\
\hline Rule 4 & $\begin{array}{l}\text { sectoral choice: } \\
\text { demand }\end{array}$ & + & $\begin{array}{l}\text { Turks in the sector: } \\
\text { increasing }\end{array}$ & + & $\begin{array}{l}\text { clients: } \\
\text { more Turks }\end{array}$ & $\begin{array}{l}\text { sector: } \\
\text { FIRE }\end{array}$ \\
\hline Rule 5 & $\begin{array}{l}\text { education place: } \\
\text { Netherlands }\end{array}$ & + & $\begin{array}{c}\text { previous sector: } \\
\text { employee in the same sector }\end{array}$ & + & $\begin{array}{c}\text { clients: } \\
\text { more Turks }\end{array}$ & $\begin{array}{l}\text { sector: } \\
\text { FIRE }\end{array}$ \\
\hline \multicolumn{7}{|c|}{ Sectoral Choice } \\
\hline Rule 1 & $\begin{array}{l}\text { information source: } \\
\text { own experience }\end{array}$ & + & $\begin{array}{l}\text { clients: } \\
\text { more Turks }\end{array}$ & & & $\begin{array}{l}\text { sectoral choice: } \\
\text { demand }\end{array}$ \\
\hline Rule 2 & $\begin{array}{c}\text { previous sector: } \\
\text { entrepreneur in different sector }\end{array}$ & & & & & $\begin{array}{l}\text { sectoral choice: } \\
\text { demand }\end{array}$ \\
\hline Rule 3 & $\begin{array}{l}\text { education place: } \\
\text { Netherlands }\end{array}$ & + & $\begin{array}{c}\text { position before start: } \\
\text { employed }\end{array}$ & + & $\begin{array}{l}\text { sector: } \\
\text { ICT }\end{array}$ & $\begin{array}{c}\text { sectoral choice: } \\
\text { education\&experience }\end{array}$ \\
\hline Rule 4 & $\begin{array}{c}\text { education level: } \\
\text { university }\end{array}$ & + & $\begin{array}{c}\text { preferences for employees: } \\
\text { Dutch }\end{array}$ & & & $\begin{array}{c}\text { sectoral choice: } \\
\text { education\&experience }\end{array}$ \\
\hline
\end{tabular}


Table 14 Most important factors in motivation, driving forces and sectoral choice of the secondgeneration Turkish entrepreneurs in the ICT and the FIRE sectors

\begin{tabular}{|l|l|}
\hline Rank of order & ICT/FIRE sectors \\
\hline 1 & Nationality of employees \\
\hline 2 & Preferences of employees \\
\hline 3 & Target group \\
\hline
\end{tabular}

Table 15 Determining factors for sectoral choice

\begin{tabular}{|l|l|}
\hline ICT sector & FIRE sector \\
\hline Education attainment & Existence of Turkish entrepreneurs in the sector \\
\hline Working experience & Existence of potential Turkish clients \\
\hline & Perceived demand \\
\hline
\end{tabular}

